\title{
Outcomes of Observance Privacy in Hospitalized Patients: A Qualitative Content Analysis
}

\author{
Tayebeh Hasan Tehrani' ${ }^{1}$, Sadat Seyed Bagher Maddah², Masoud Fallahi-Khoshknab*3, Farhnaz \\ Mohammadi Shahbooulaghi ${ }^{4}$, Abbas Ebadi ${ }^{5}$ \\ 1. Assistant Professor, Mother and Child Care Research Center, Hamadan University of Medical Sciences, Hamadan, \\ Iran \\ 2. Assistant Professor, Department of Nursing, University of Social Welfare and Rehabilitation Sciences, Tehran, Iran \\ 3. Professor, Department of Nursing, University of Social Welfare and Rehabilitation Sciences, Tehran, Iran \\ 4. Associate Professor, Department of Nursing, Iranian Research Center on Aging, University of Social Welfare and \\ Rehabilitation, Tehran, Iran \\ 5. Professor, Behavioral Sciences Research Center, Life Style Institute, Faculty of Nursing, Baqiyatallah University of \\ Medical Sciences, Teheran, Iran
}

\section{Article Info}

Received: 2019/03/30;

Accepted: 2019/07/14;

Published Online: 2019/08/28

$\underline{10.30699 / \mathrm{sjhnmf} .27 .6 .441}$

Original Article

Use your device to scan and read the article online

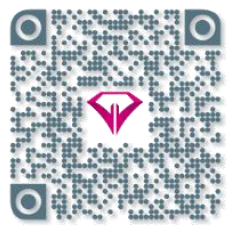

\section{ABSTRACT}

Introduction: In medical ethics, privacy is one of the main aspects of patient rights. Since the outcomes of respecting privacy as one of the dimensions of patient's rights are not clear, this study was performed to explore outcomes of observance for patient privacy in hospital.

Methods: This study was conducted with qualitative research approach and contractual content analysis method. Participants included 20 patients hospitalized in the internal and surgical wards of Tehran's hospitals who were selected based on purposeful sampling. Data was collected using semi-structured interviews. Then data was analyzed based on conventional content analysis method and using the MAXQDA 10 software.

Results: Analyzing the interviews with patients, 56 primary codes, 13 subcategories and 4 themes were extracted, which indicated the perception of participants for consequences of observance for privacy. These themes included: preservation and promotion of the dignity of the patient, compromise with the existing situation, health development and satisfaction.

Conclusion: The results of this study showed outcomes of observance for patient's privacy. With the treatment team's awareness of these consequences, the patients' expectations are respected, which leads to the provision of favorable health care and patient satisfaction.

Keywords: Outcome, Privacy, Patients, Qualitative research

\section{How to Cite This Article:}

Hasan Tehrani T, Fallahi-Khoshknab M, Seyed Bagher Maddah S, Mohammadi Shahbooulaghi F, Ebadi A. Outcomes of Observance Privacy in Hospitalized Patients: A Qualitative Content Analysis. Avicenna J Nurs Midwifery care. 2019; 27 (6) :441-450 


\section{ييامدهاى رعايت حريم خصوصى بيماران بسترى در بيمارستان: تحليل محتواى كيفى \\ طيبه حسن طهرانى'، سادات سيد باقر مداح'، مسعود فلاحى خشكناب" ‘، فرحناز محمدى شاهبلاغى؟؛

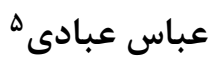

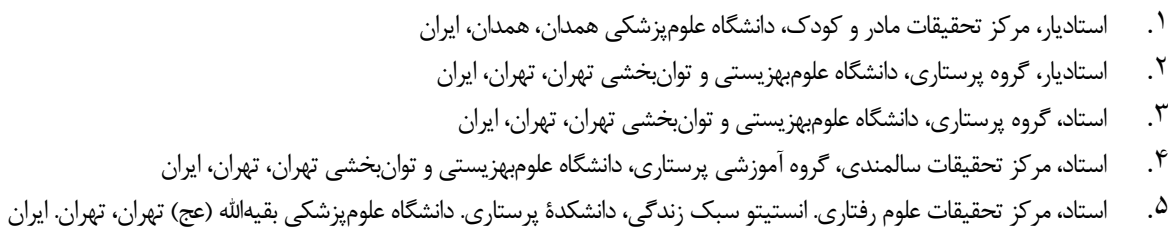

\begin{tabular}{|c|c|}
\hline جكيده & اطلاعات مقاله \\
\hline 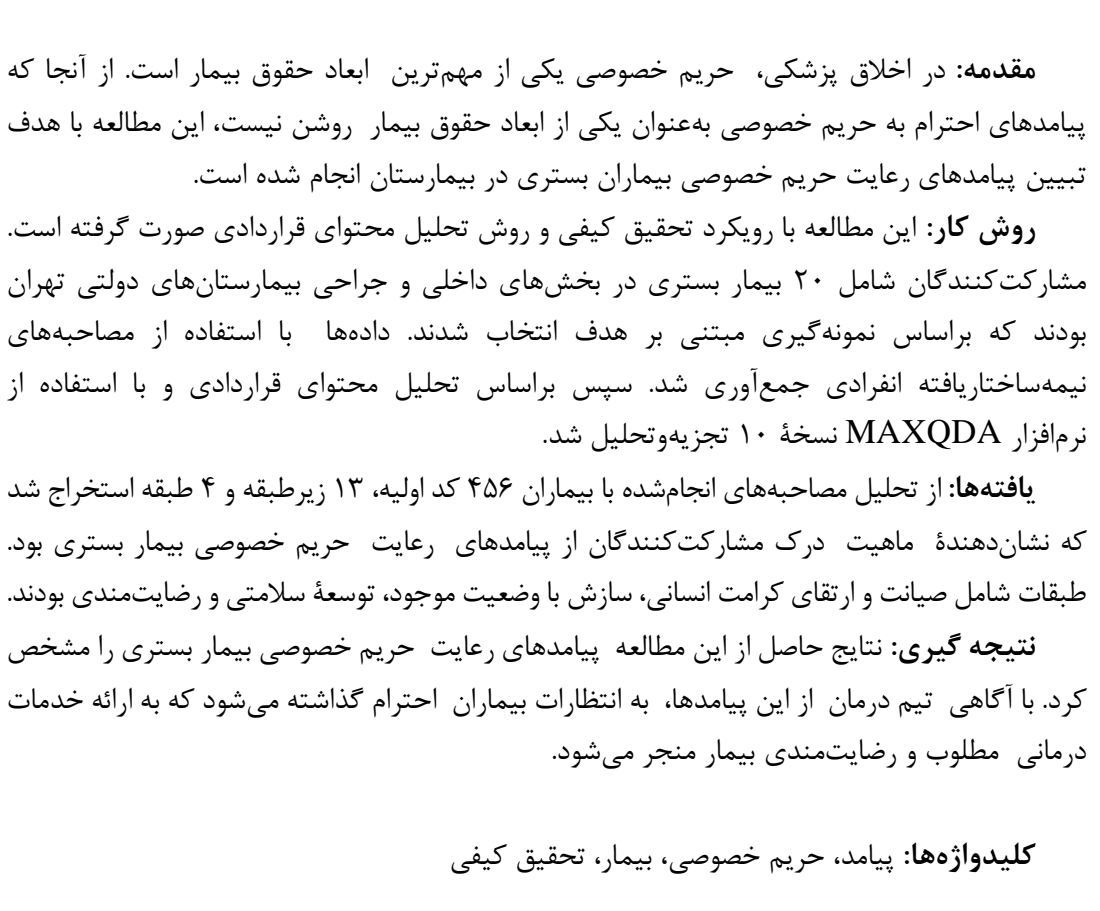 & 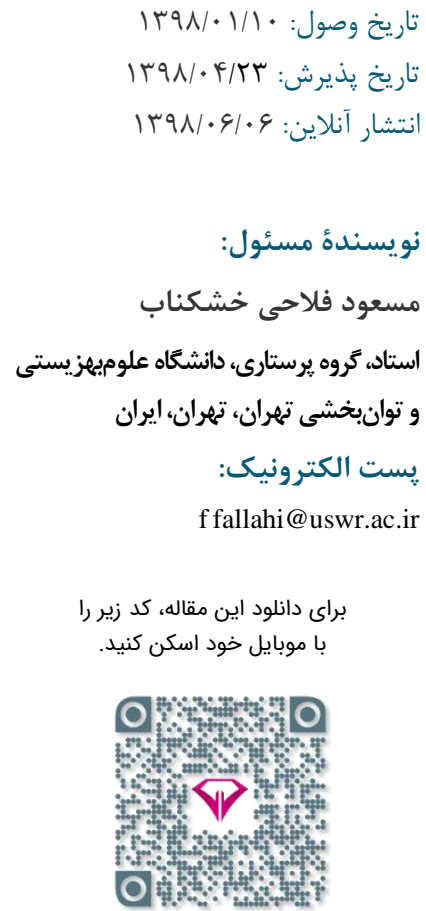 \\
\hline
\end{tabular}

مقدمه

الزامى است و يكى از قوانين حرفهاى اين رشته محسوب مىشود [ه]؛ زيرا بيماران از نظر جسمى، روانى، اجتماعى و إنى

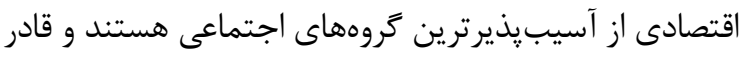

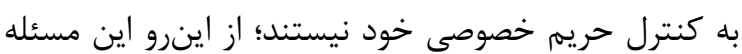

$$
\text { اهميت ويزهاى مى يابد [ع]. }
$$

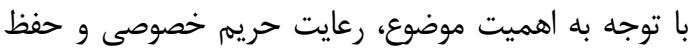
اسرار بيماران يكى از اصول اساسى استاندارهاى مراقبتى سازمانها و انجمنهاى بينالمللى يرستارى، از جمله شوراى بينالمللى يلى

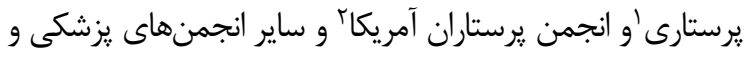

در فرهنَ آكسفورد معناى حريم خصوصى يا معادل

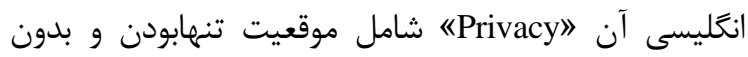

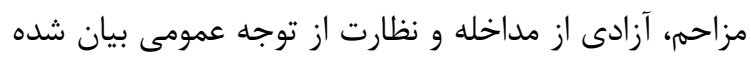

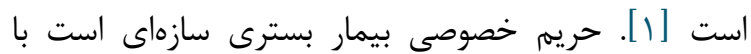
جندين بعد از جمله فيزيكى، اطلاعاتى، روانى- اجتماعى و

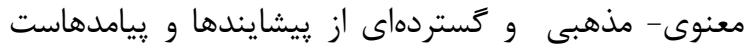
[Y]. حريم خصوصى معانى خاص و ويزهاى در سيستمهاى

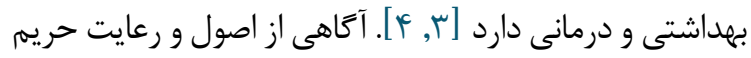
شخصى بيماران براى كاركنان نظام سلامت، بلويزه يرستاران

\section{ICN}


ماندهاند. با مشخصكردن دليل خاص و توضيحى ساده

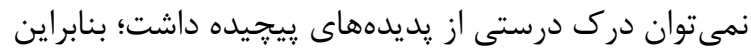

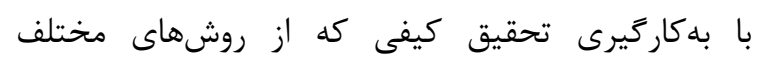

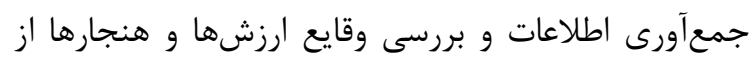

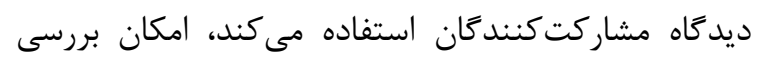

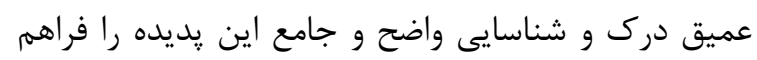

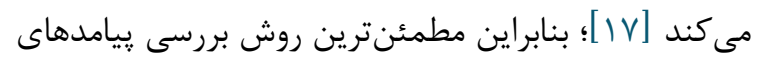

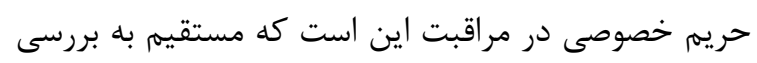

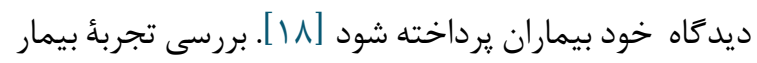

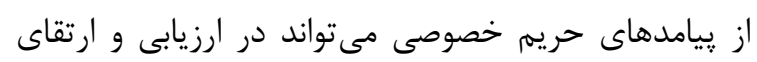

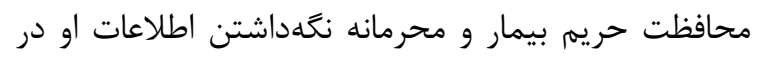

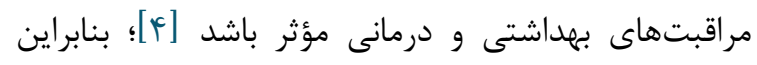

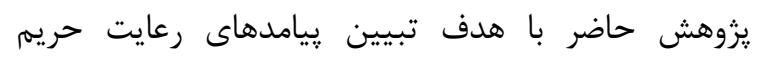
خصوصى بيماران بسترى در بيمارستان انجام شد. بيامد

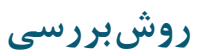

در اين مطالعه، بهمنظور توصيف تجربيات بيماران

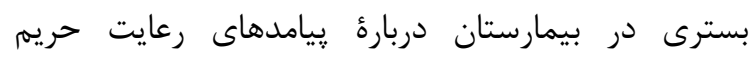

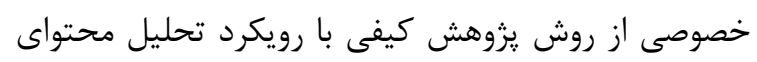

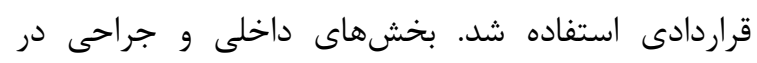

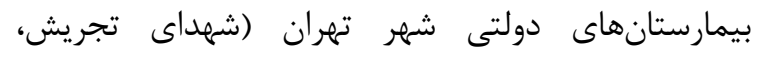
طالقانى) براى عرصؤ مطالعه انتخاب شدند. براى انتخاب

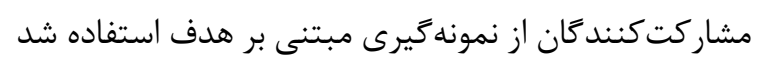

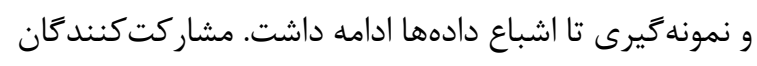

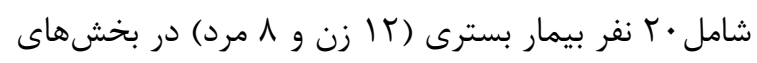

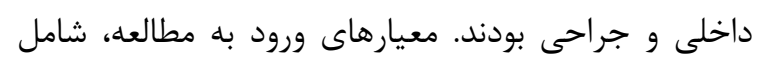

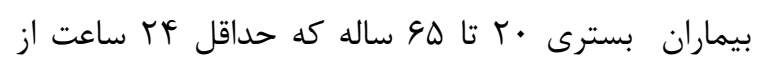

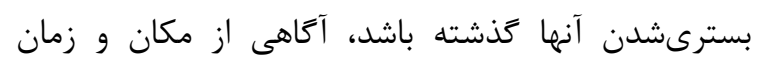

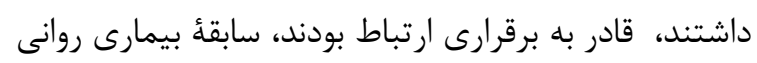

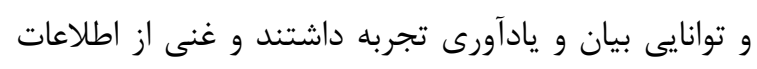

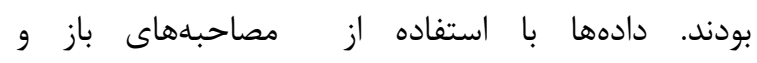

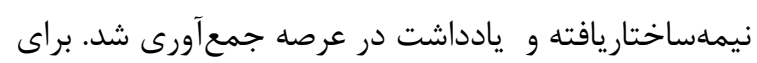

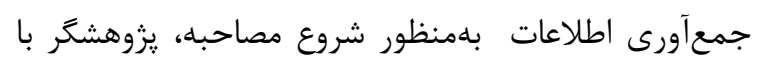

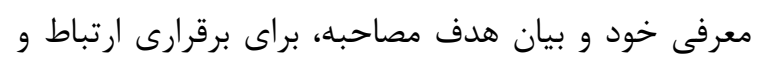

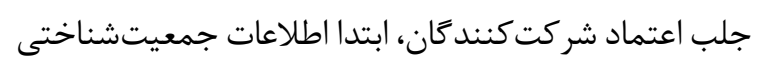

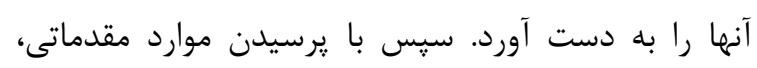

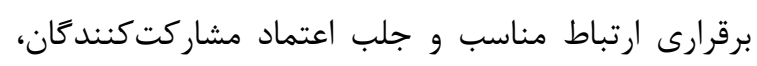

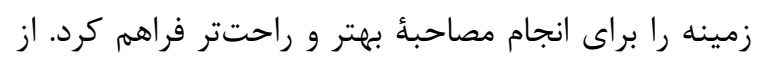

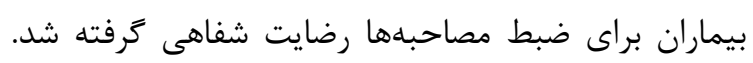

بيرايزشكى است [V]]. در ايران نيز نمونههايى از اسناد اخلاقى،

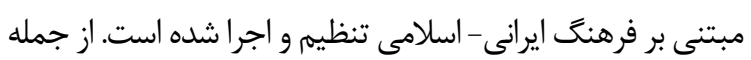

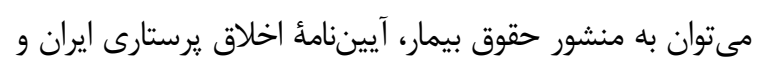

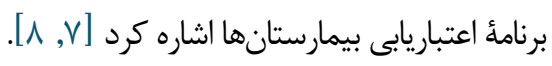
در سالهاى اخير، مطالعات زيادى در زمينهٔ حريم خصوصى بيماران انجام شده است. با وجود تأكيد زياد بر دران

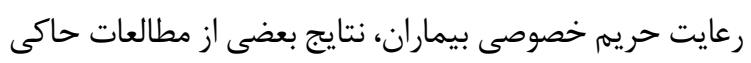

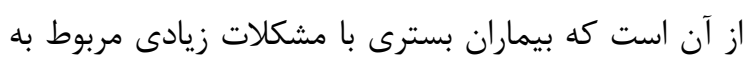

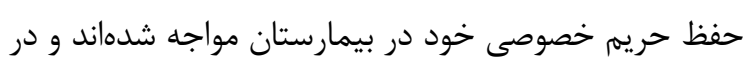

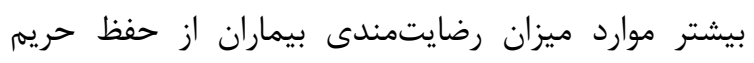

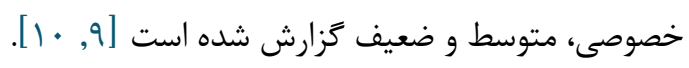

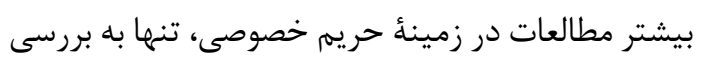

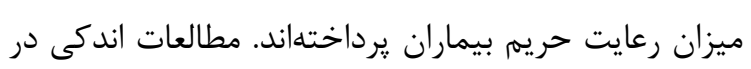
زمينهُ يِيامدهاى رعايت حريم خصوصى بيت بيماران بردان انجام شده

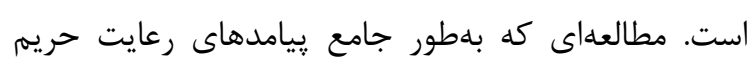

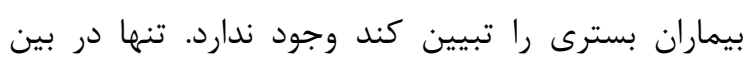

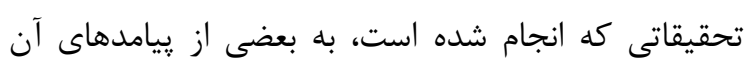

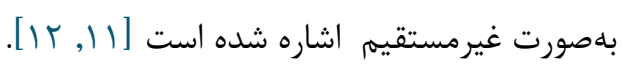

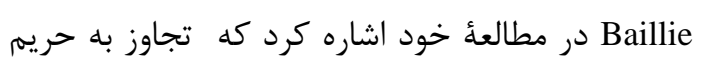

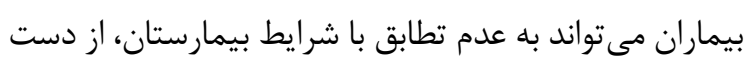

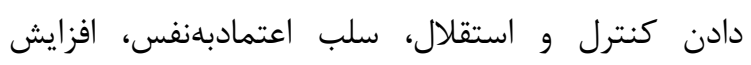

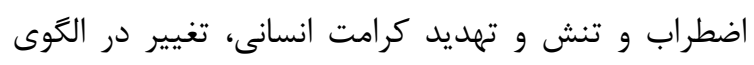

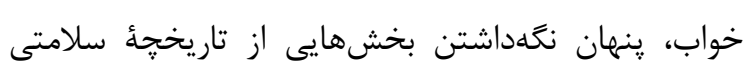

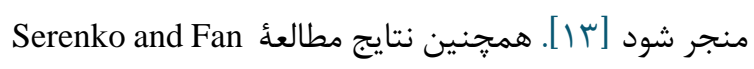
نشان داد رعايت حريم شخصى بيمار ان در ايجاد ارتباط مؤثر

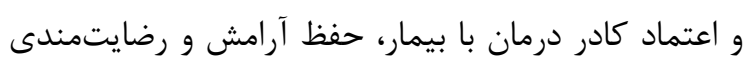

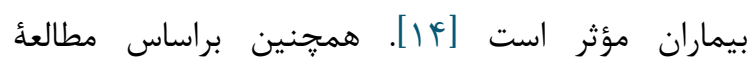

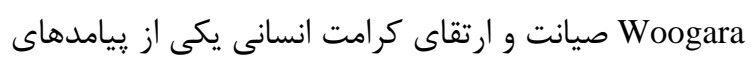

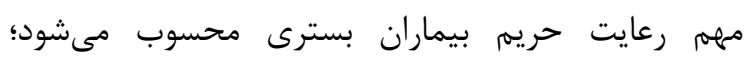

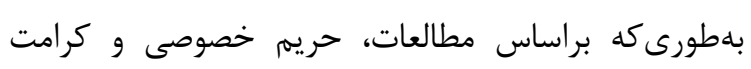

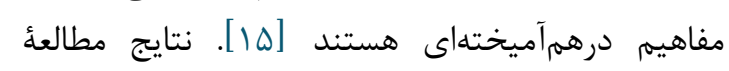

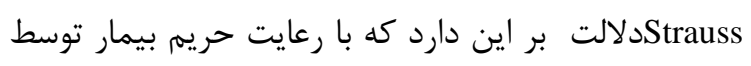

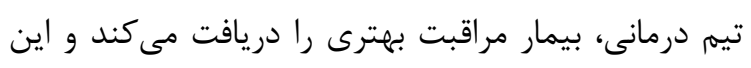
عامل شاخصى از ارزيابى كيفيت مراقبت است؛ زيرا برا احترام

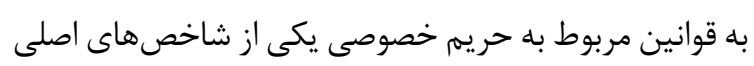

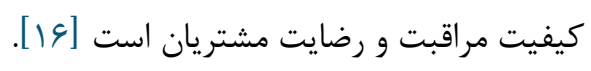

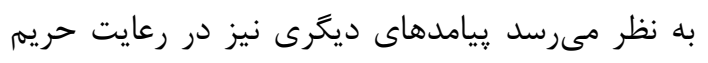

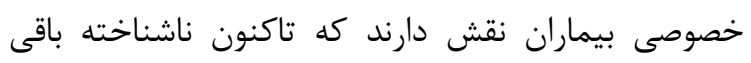


بهدستآمده در اختيار سه نفر از يزوهشكران كيفى قرار

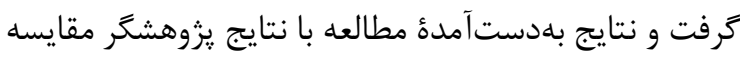

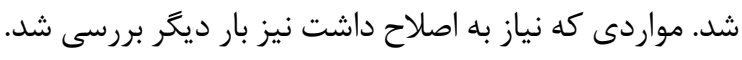

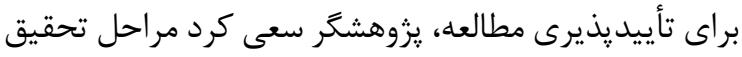

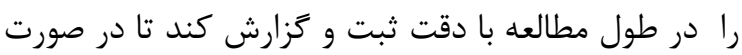
نياز امكان مطالعه از سوى ديكران فراهم شود. جهت ترك تأمين

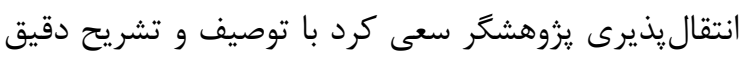

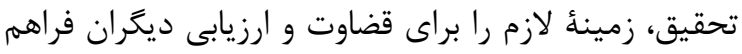

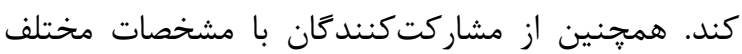
بلهورت هدفمند دعوت به عمل آورد. اصول اخلاقى يزوهش شامل تصويب طرح در شوراى

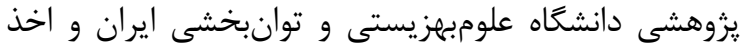

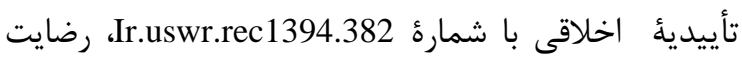

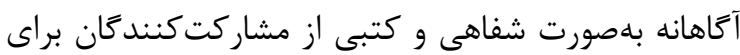
شركت در مطالعه، اجازء از آنها از ضبط صدا، اطميناندادن آنان ماندان

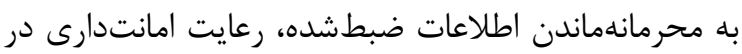
متن مصاحبهها و استقلال آنها براى انصراف از مطالعه بود.

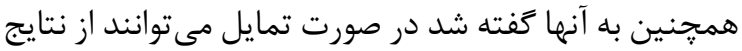

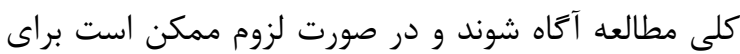
تكميل صحبتها دوباره به آنها مراجعه شود.

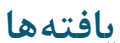

از تحليل مصاحبهها با بيماران ؤه كد اوليه، با زا زيرطبقه

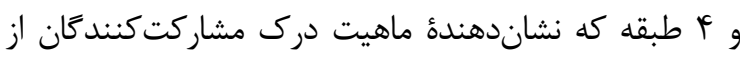
ييامدهاى رعايت حريم خصوصى بيمار بسترى بود استخراج شد. كدها براساس شباهتها با يكديخر ادغام شدند. سيس إين

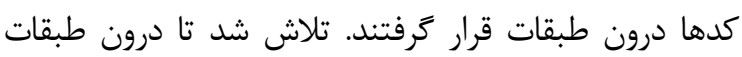

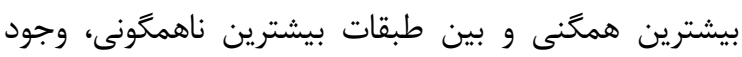
داشته باشد و هيج دادهاى درون دو طبقه قرار نخيرد. طبقات

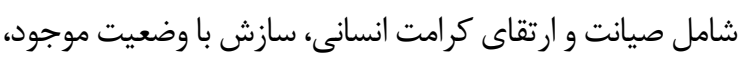
توسعه سلامتى و رضايتمندى بودند (جدول (1).

\section{صيانت و ارتقاى كرامت انسانى}

اولين קيامد حريم خصوصى بيماران بسترى در بيمارستان،

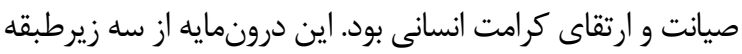

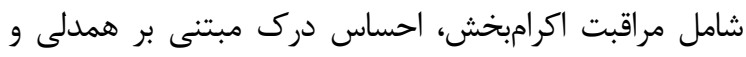
احترام به بيمار و خانوادهاش تشكيل شده است. همأ بيماران احتران بلهطور مستقيم و غيرمستقيم در تجارب خود، در قالب مراقبت اكرامبخش، همدلى و احترام به بيمار و خانوادهاش اشاره كردند.
مصاحبهها بهصورت انفرادى در محيطى آرام و در زمان و مكانى كه شركت كنندكان احساس راحتى مى كردند، انجام

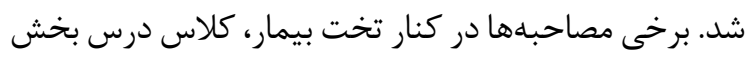
يا در حياط و فضاى سبز بيمارستان انجام شد. يُ إس از سؤالات مقدماتى مصاحبه با يك سؤال كلى و باز آغاز شد؛ براى مثال

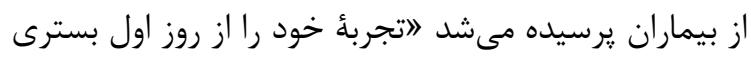

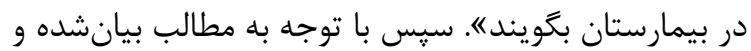

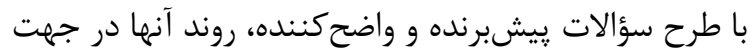

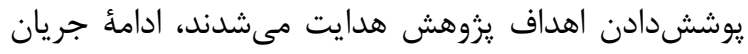
مصاحبه تا حد زيادى متكى بر سؤالاتى بود كه در تعامل مصاحبه تجربهاى از رعايت يا عدم رعايت خود را بيان مىكرد، از او

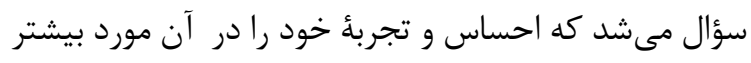

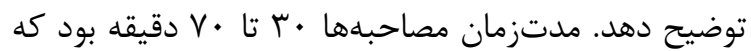
در طى 9 ماه متوالى انجام شد.

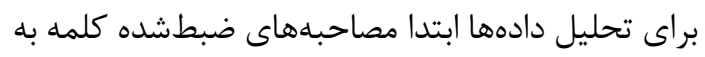

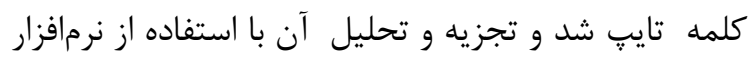
MAXQDA با بتفاده از مراحل ييشنهادى Graneheim and Lundman

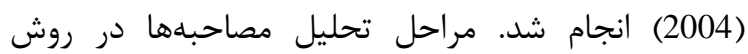
كرانهايم و لاندمن شامل اجراى هر مصاحبه بلافاصله بعد از هر مصاحبه، خواندن متن كامل مصاحبه براى درك كلى كلى آن،

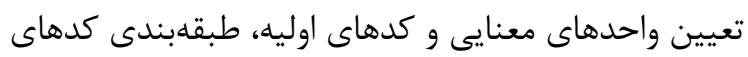
اوليه مشابه در طبقات جامعتر و تعيين معناى نهفته در دادههاست [19].

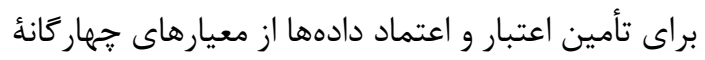

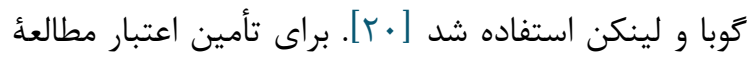
يافتهاى بهدستآمده به ه نفر از شركت كنندكان و و

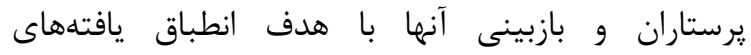

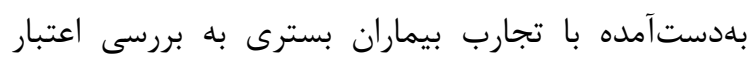

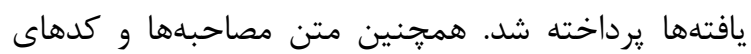
استخراجشده در اختيار استادان تيم تحقيق و دو نفر از

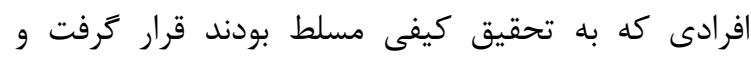

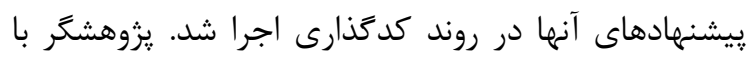
دركيرى طولانىمدت با يديدهٔ مورد نظر و غوطهورى كامل

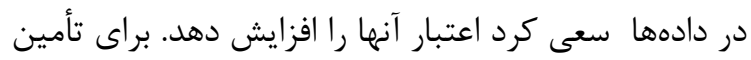

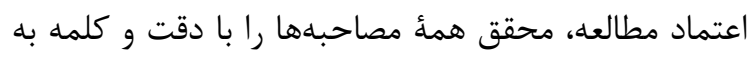
كلمه نوشت و تايب كرد. همجنين تحليل دادههاى هماى 
جدول ا. طبقات اصلى و زيرطبقات يِيامدهاى رعايت حريم خصوصى در بيماران بسترى ايرانى

\section{كدهاى اوليه}

رهانكردن بيمار حين ويزيت، احترام به بيمار هنخام مراقبت، احترام دانشجويان در حين ويزيت

دلدارىدادن برستاران، احواليرسى موقع ويزيت، اميدوارى به بيمار

مؤدببودن كاركنان، احترام به بيمار در بسترى مجدد، احترام نتُهبان به همراه و ملاقاتىها، خوشبرخوردى با همراه

انتظار نقض حريم در اتاقهاى خندتخته، انتظار بيمار از استانداردهاى پاييين، قانعبودن بيماه بهاقداقل ها، درك از كمبود كاركنان

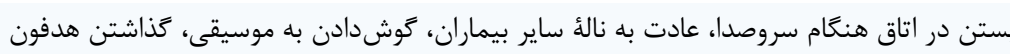

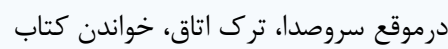

تذكر به ملاقاتى ساير بيماران، تذكر به كاركنان با شوخى، مذاكره با كاركنان در نقان نق حرياب حريم، شكايت

$$
\text { قانونى ببمار }
$$

تمامشدن تحمل بيمار، يُيگيرى درمان توسط بيمار، همكارى با تيم درمان در انجام يروسيجرها

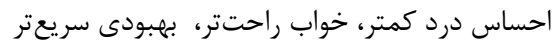

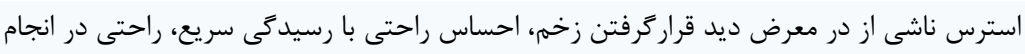

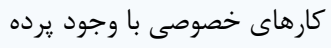

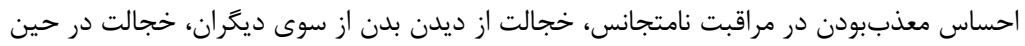
معاينه با حضور دانشجويان

احساس امنيت با وجود يرده، احساس امنيت با قفل توالت، احساس عدم امنيت از برخى بران رفتارهاى كاركنان

رضايت از احواليرسى، خشنودى از صميميت كاركنان، خرسندى از احترام به بيمار و همراه، موافقت با رفتار انسانى كاركنان

رضايت از خلوتى بخش، رضايت از تعداد ملاقاتىها، احساس رضايت از هماتاقى با بيماران همعن،

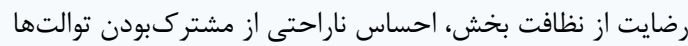

مراقبت اكرامبخش

احساس درك مبتنى

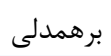

احترام به بيمار و و بدلي

صيانت و ارتقاى كرامت انسانى بيمار و وريان

خانوادهاش

انتظار نقض حريم

انعطاف با عدم رعايت

سازش با وضعيت

حريم

موجود

مذاكره و برخورد

قانونى با ديخران

تمكين در مراقبت

سلامت جسمى

آسودَى در مقابل

تشويش

خجالت در مقابل

خانواده

راحتى

احساس امنيت در

مقابل نامنى إنى

خشنودى از ارتباط نامنى

بينفردى تيم درمان

رضايتمندى بيمار

رضايت از نظم بخش
بيشتر بيماران بيان مى كردند درك احساسات و ارزشهاى

آنها در حين مراقبت، يايه و اساس مراقبت محسوب ميىشود و با بـ رعايت حريم بيمار احساس همدلى كاركنان را حس مين مئ مردند. در اين زمينه، يكى از مشاركت كنند رزيدنت و يرستارها بيشتر به فكر اينن كه يرونده بيمار تكميل

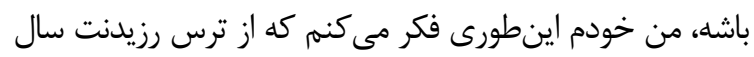

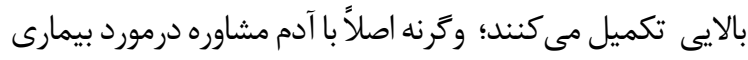

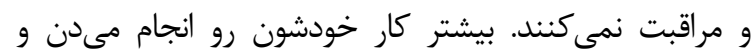
مىرن.آدم حس مى كنه، اصلًً براشون مهرم نيست مريض جه

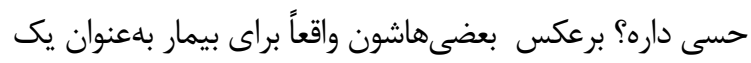

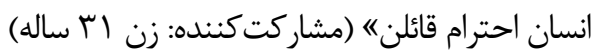
درمورد احترام به بيمار و خانوادهاش يكى از بيماران اظهار

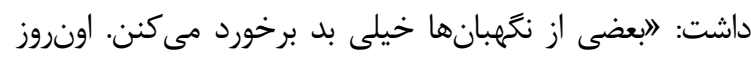
داماد من اومده، ساعت ملاقات تمام شد. يكى از دخترهام ماند و
مشار كت كنندكان طى مراقبت، احساس تكريم يا عدم تكريمم خود را با تجاربى مانند رهاكردن بيمار در حين ويزيت، معطلى مريلى بيمار بلوسيلة جراح، معاينهُ سريع، احترام به بيمار در حين

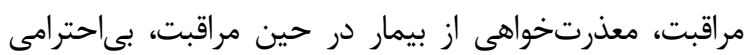
رزيدنتها در حين معاينه و... بيان مى كردند. مشاركت كنندهاى در اين زمينه بيان كرد: إيرستارم خانم... خيلى مؤدب است، دئس خيلى دلسوز است، خيلى خوشبرخورد است؛ مثل دختر خودم

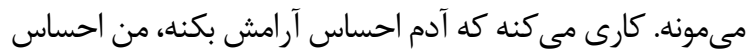
بهترى باهاش دارم احساس راحتى دارم. وقتى صحبت و و ماردى درخواستى دارم سريعاً كارم را انجام مىده و رسيدگى راحى مى كنه.

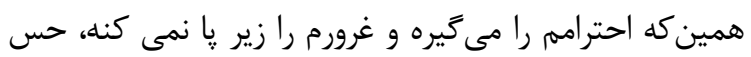

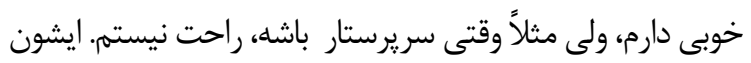
شايد بهخاطر پستى كه دارند، اينطورى هستن نمى دونم (مشاركت كننده: مرد ول ساله). 
شبها ما مىخوابيم، اينطورى مى كنى، ما خوابمون نمىبره. ديكه

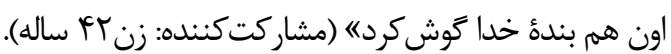

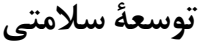

اين درونمايه شامل جهار زيرطبقة سلامت جسمى،

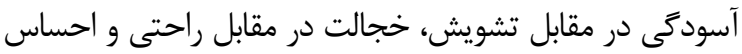

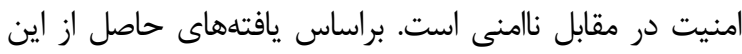
مطالعه مشخص شد، رعايت حريم بيماران بسترى در بيمارستان، منابن

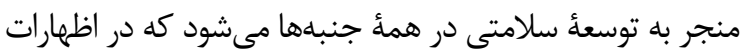
شركتكنندكان مشهود بود. يكى از مشاركت كنندكان در اين اين زمينه بيانكرد: ابعضى يرستارها عذرخواهى بلد نيستن.

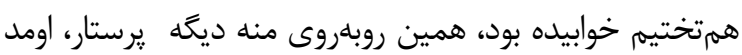

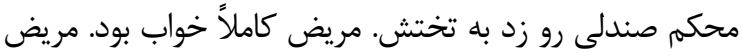

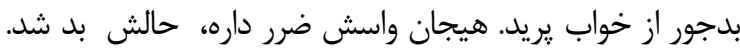

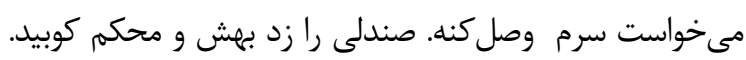

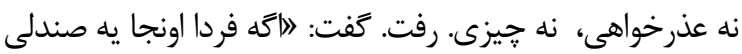

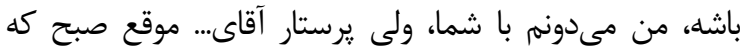

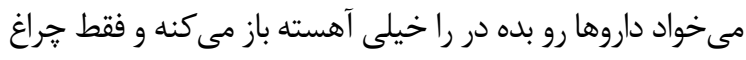
خواب بالاى سر هر بيمار را روشن مى كنه كه بقار بقيه بيدار نشنه

(مشاركت كننده: مرد 1) الهاله).

مشاركت كنندة ديكر بيان داشت: الهر اتاق دو تخت داره و

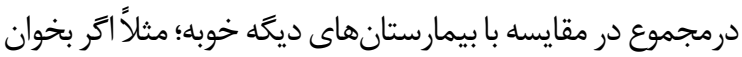
كارى براى من انجام بدن، مقابل بيماران هماتاقىام احساس دراس

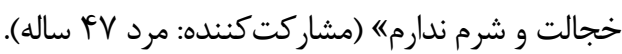

\section{رضايتمندى بيمار}

آخرين ويزگى رعايت ريندى يدمار حريم خصوصى بيماران بسترى در بيمارستان كه بلصورت مستقيم يا غيرمستقيم از بيانات بيماران استخراج شد، رضايتمندى بيمار بود كه شامل دو زيرطبقان إنهان

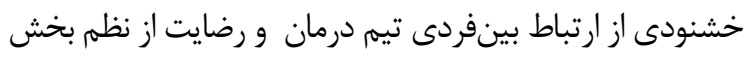

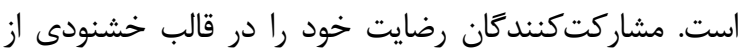
ارتباطات بينفردى تيم درمان و رضايت از نظم بخش اظهار

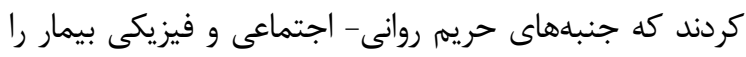
تحت تأثير قرار مى داد. بيشتر بيماران ابراز مىكردند كهد

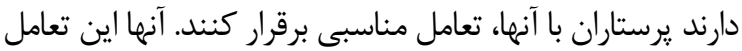
را روحيدبخش و احترام به حريم اجتماعى خود در نظر مى گرف نتند

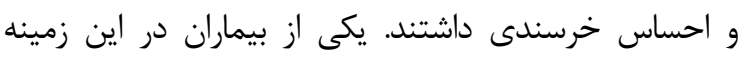
بيانمى كرد: الوقتى يرستار و يزشك در موقع ويزيت و مراقبت باليا

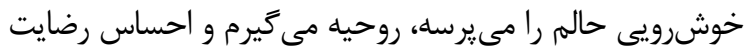

دور و بر من بود. دامادم رفته دمآسانسور ايستاده كه با خانمش بره يايين نكَهبان داد زده سرش كه البرو، بروه، كفت مىرم. كفت:

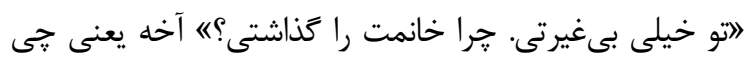

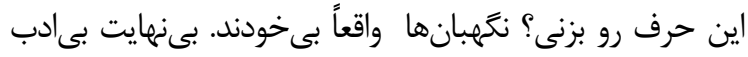
هستند. البته همشون اينطورى نيستند، بعضىهاشون خيلى

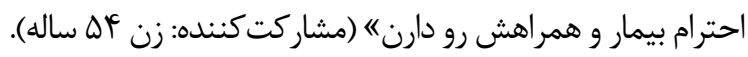

\section{سازش با وضعيت موجود}

بيامد ديخر رعايت حريم بيماران بسترى، سازش اجبارى با وضعيت موجود استخراج شد. اين درونمايه از سه زيرطبقة انتظار

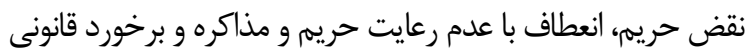
با ديكران تشكيل شده است. با توجه به بيانات بيماران با وجود

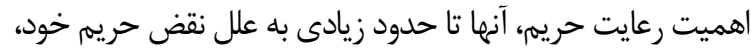

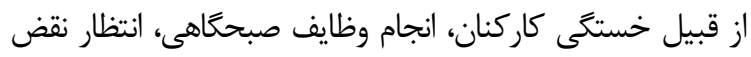
حريم در اتاقهاى جندتخته، انتظار بيمار از استانداردهاى بإيين،

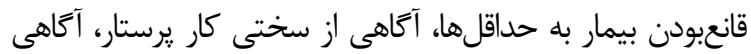
نسبت به مشكلات بيمارستان دولتى و... آكاهى داشته و و يذيرفتئه

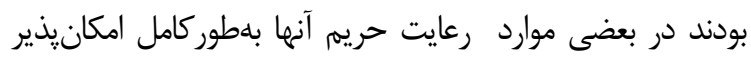

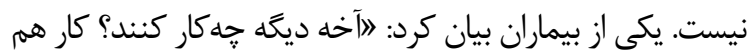
مونده ديكه؟ الآن كارمندى كه مياد اينجا از صبح كه خشمه بذارى بـان

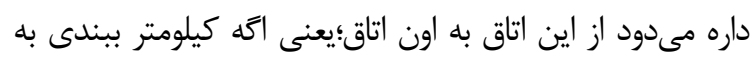

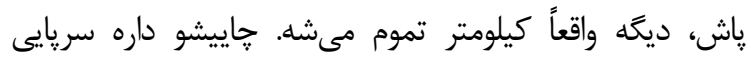
مىخوره. يس إين با جه روحيداى بياد طرف مريض و شرايط

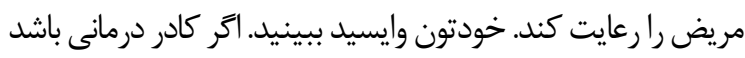

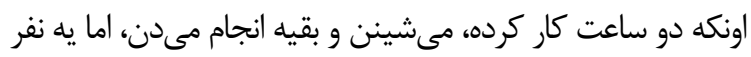
آدمه از اين اتاق به اون اتاق كادر بهداشتى -درمانى كم است. خيلى كم داريم" (مشاركت كننده: مرد بأ ساله).

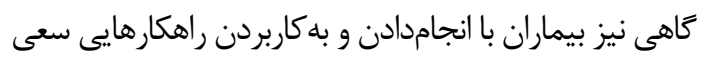
مى كنند با شرايط عدم رعايت حريم، سازكارى يابند يا به مذاريره با ديخران بيردازند. مشاركت كنندهاى مى كويد: ابعضى كاركنان در نمىزنند. اجازه هم نمى يَيرند، ولى صدا مى كنيند. در هميشه باز است و هر وقت بخواهند مى آيند مىروند. اكر خيلى سئ سروصدا باشه، خودمان در را مىبنديم، ولى بعضىها هم رعايت مى كنئد

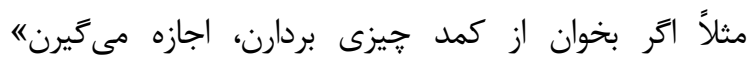
(مشاركت كننده: زن آس ساله). مشاركت كننداى ديكر بيان كرد: "إرا يه وقتهايى، مثلاً اين

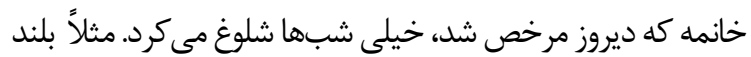

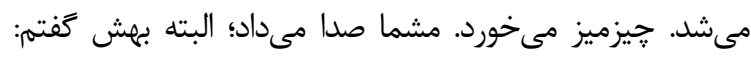


يكى ديكر از يبامدهاى عدم رعايت حريم در بيماران بسترى مشاركت كنندكان سازش با وضعيت موجود استخراج

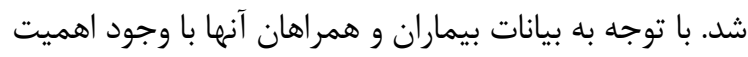

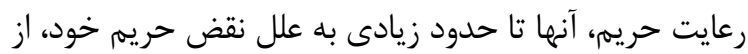

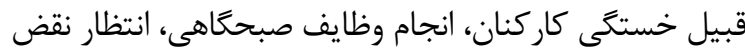
حريم در اتاقهاى קندتخته، انتظار بيمار از استانداردهاى

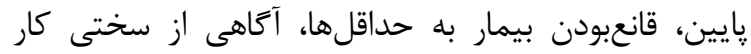
يرستاران و كاركنان تيم درمان، آكاهى از مشكلات بيمارستان

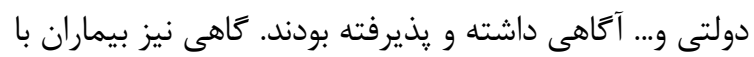

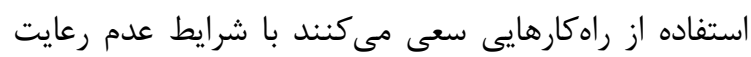

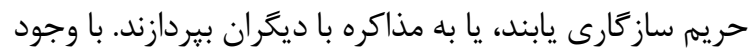
تصويب منشور حقوق بيمار در ايران هنوز در ميان مراقبان

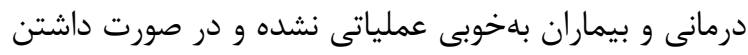

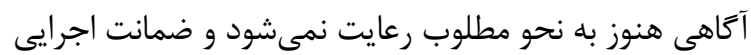
آن تضمين شده نيست. ييامد تطابق با عدم رعايت حريم در

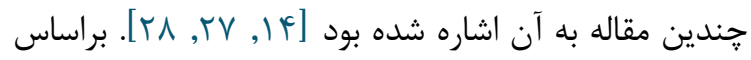

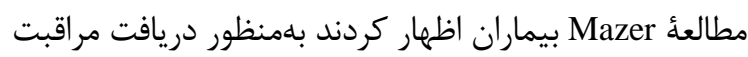
در شرايط اورزانسى با توجه به شرايط موجود از حريم

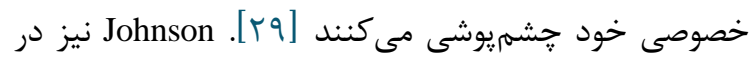

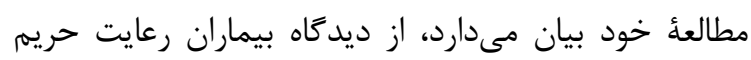

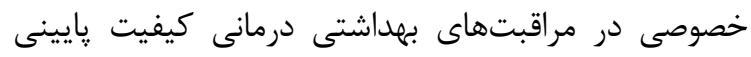
برخوردار است. با وجود اين، بسيارى از بيماران به استاندارهاى دئي

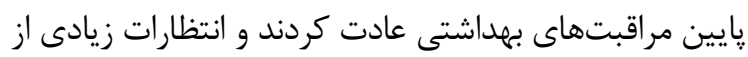
رعايت حريم خصوصىشان ندارند [•rّ]. تحليل دادهها نشان مىدهد رعايت حريم بيماران بسترى در بيمارستان منجر به توسعأ سلامتى در همأ جنبهانها مىشود كه در اظهارات شركت كنند يافتهها با بعضى از مطالعات انجامشده همراستا بود [4 أئ. براساس مطالعات انجامشده، زمانى كه حريم خصوصى بيمار

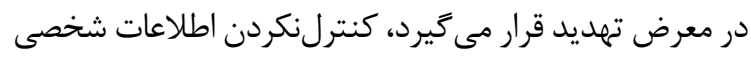

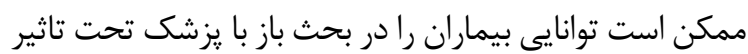

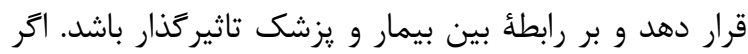

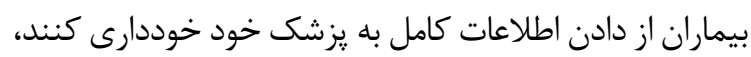

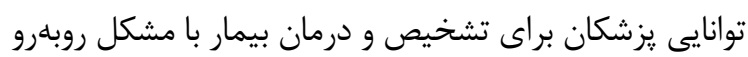

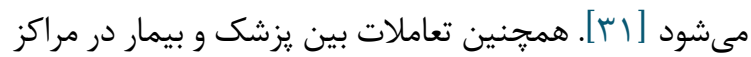

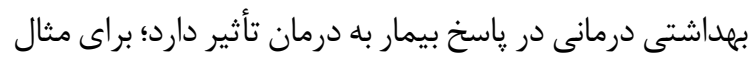

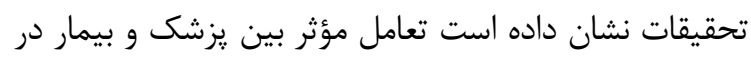
بهبود فشارخون، قند خون و درد بيمار مؤثر بوده و روند
درونى دارم. اينطور برخوردكردن باعث مىشه آدم دردش رو فراموش كنه/ (مشاركت كننده: زن لهأ ساله).

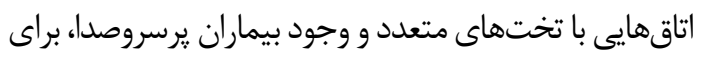
بيماران آزاردهنده بود و حريم فيزيكى آنها را تحت تأثير قرار بار بران مىداد. يكى از بيماران در اين مورد بيان كرد: إيانسمان من در

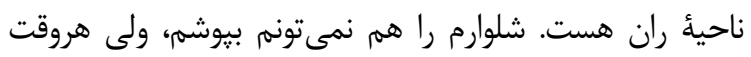

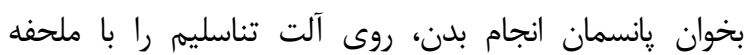
مىيوشونن و وقتى اين جيزها رو رعايت مى بكنن، كمتر خجالت

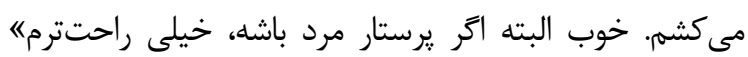

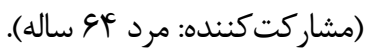

\section{بحث}

تجارب بيماران بسترى در زمينهُ ييامدهاى رعايت حريمم

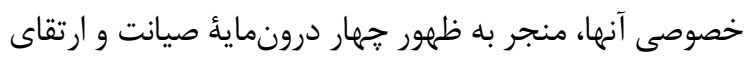

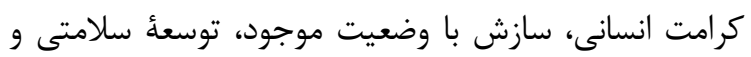
رضايتمندى بيمار شد كه در بعضى از مطالعات مشابه اين

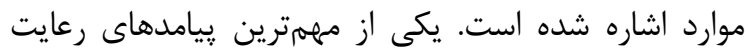

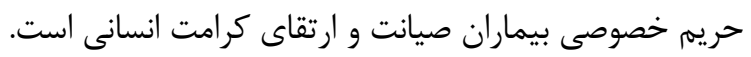
اغلب بيماران بيان كردند كه درك احساسات و ارزشهاى آنهائ آنها

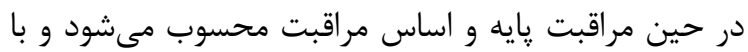

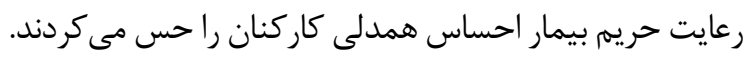

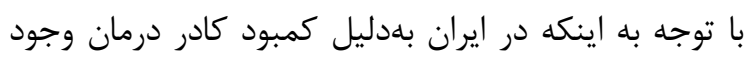

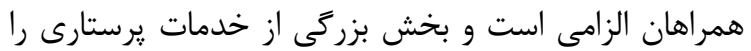

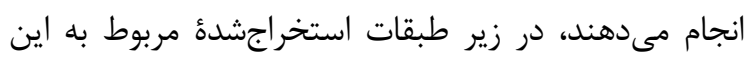
طبقه احترام به بيمار و خانواده و احساس درك همدلى آندات آنها

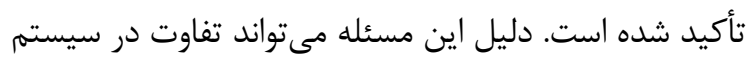
بهداشت و درمان ايران از جمله كمبود نيرو با ساير

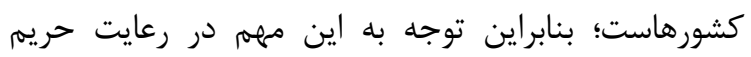

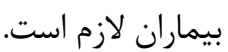
از مرور متون مىتوان نتيجه كرفت حريم خصوصى و

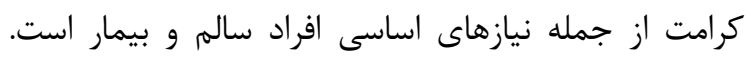
بيمارى مى تواند حفظ حريم خصوصى و كرامت بيمار را كاهش إسى

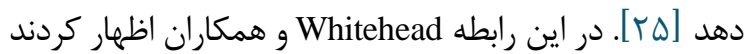
حريم خصوصى از ديدكاه بيماران و يرستاران شامل احترام،

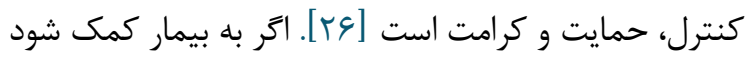
حريم خصوصىاش حفظ شود، خودكنترلى، استقلال و عزت

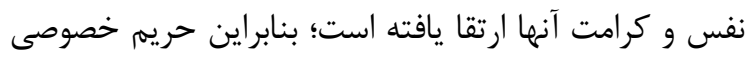

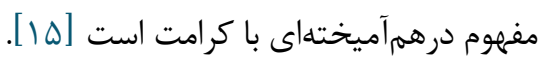




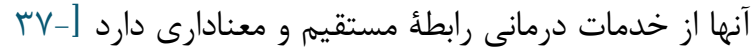

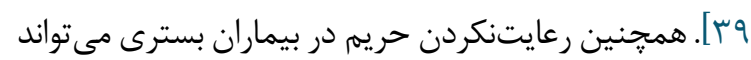

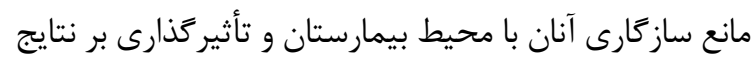

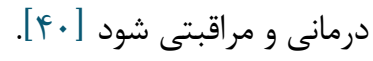

\section{نتيجه كيرى}

نتايج نشان مى دهد حفظ حريم مىتواند تاثير مهمى در افزايش رضايت، حفظ و ارتقاى كرامت بيماران داشته باشدي؛

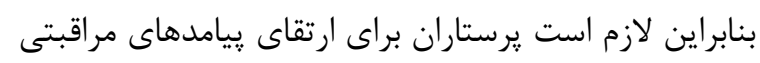

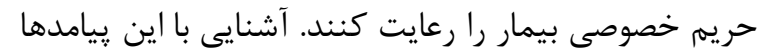

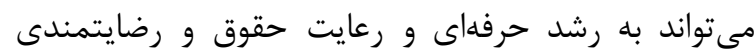
مددجويان كمك كند. همجنين نتايج حاصل از اين مطالعه

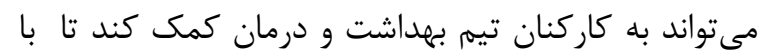
داشتن حساسيت بيشتر به حفظ حريم بيمار، انتظارات آنها

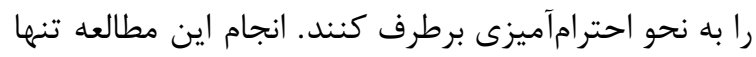

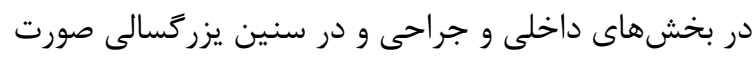

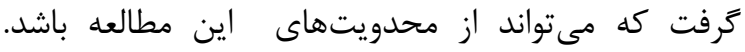

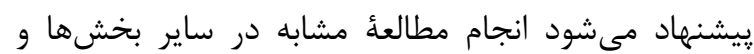

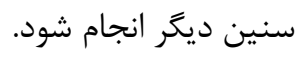

\section{سياسگزارى}

اين مقاله قسمتى از پاياننامه دكترى نويسنده اول با

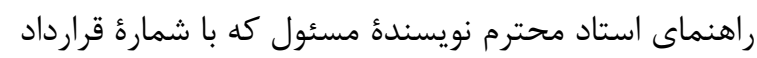

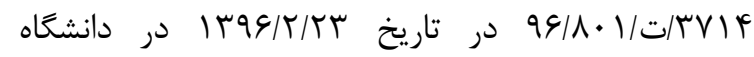
علومبهزيستى و توانبخشى به تصويب رسيده است كه حامى داري

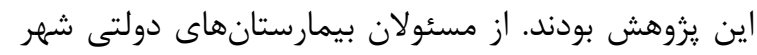

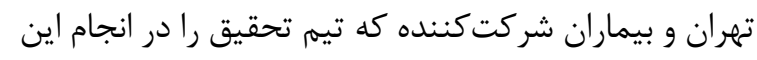

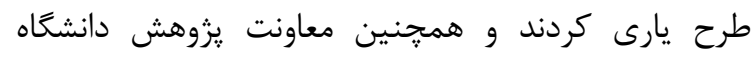

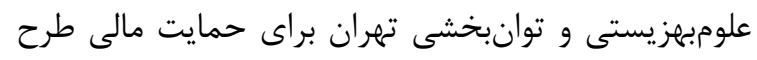
حاضر تشكر و قدردانى مىشود.

$$
\text { تعارض در منافع }
$$

بين نويسندكان هيجَّونه تعارضى در منافع وجود ندارد

\section{منابع مالى}

منابع مالى اين مطالعه توسط نويسندكان تامين شده است.
بهبودى آنها را تسريع مى كند [Tr]. اعتماد به انتظارات مثبت

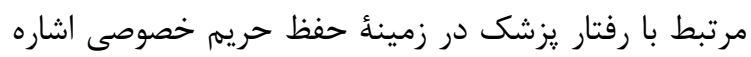

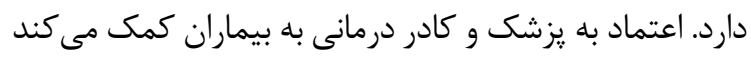

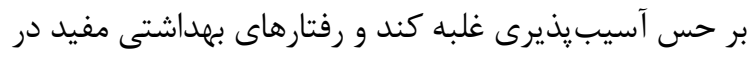

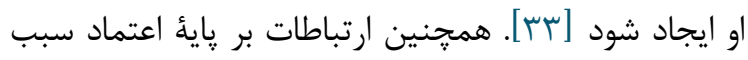

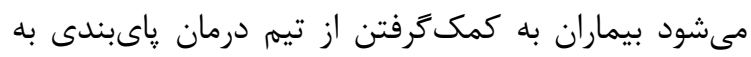

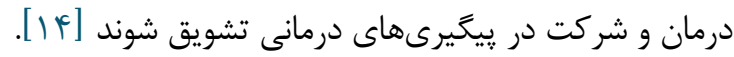

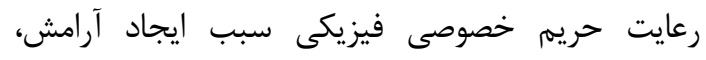

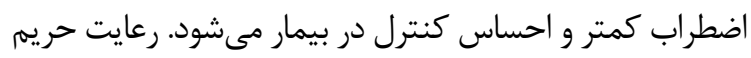
فيزيكى بيماران براى سلامتى و رفاه بيماران حيماس حياتى است.

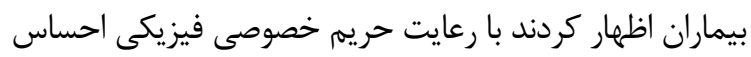

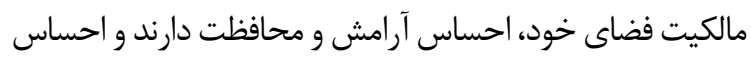

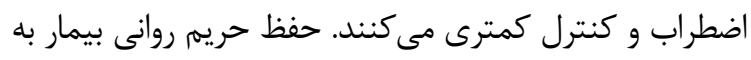

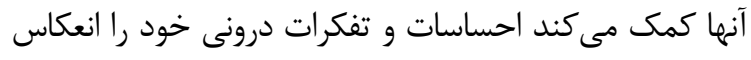
دهند و در هنخام احساس آسيبذيذيرى و بيمارى آنها كار كذاشته نشده و در بيمار حس هويت توام توانمندى و و استقلال ايجاد

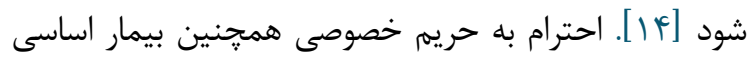

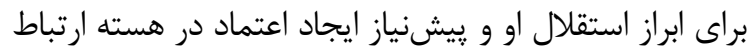

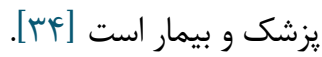
آخرين يُيامد رعايت حريم خصوصى بيماران بسترى در بران بيمارستان كه بهصورت مستقيم يا غيرمستقيم از بيانات

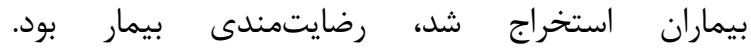

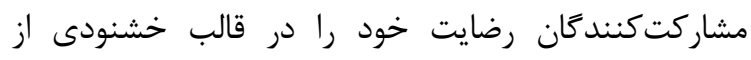

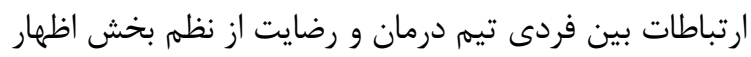
كردند كه جنبههاى حريم روانى-اجتماعى و فيزيكى بيمار را دان

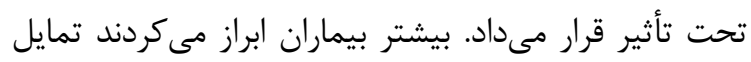

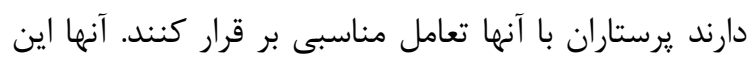

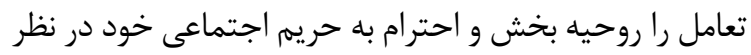

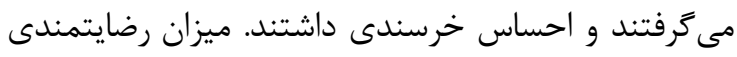
بيماران، بيانكر قابليت و توانايى يزشك و و كاركنان درين درمان

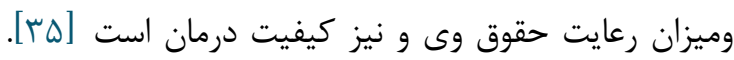

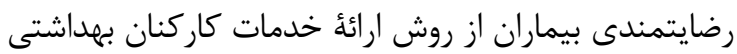

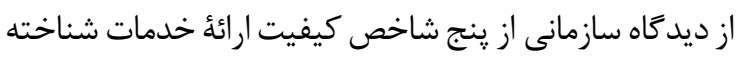

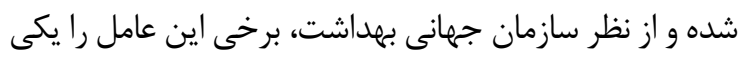
از مهمترين عوامل تعيين كنندة كيفيت خدمات سلامت مطرح

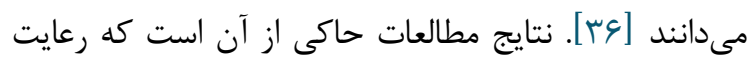

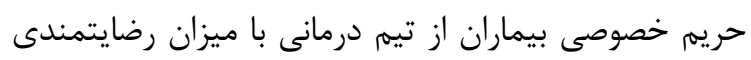




\section{References}

1. Dictionary COE. Oxford University Press. URL: http://oxforddictionaries com/(Дата обращения: 2012.

2. Hasan Tehrani T, Seyed Bagher Maddah S, FallahiKhoshknab M, Ebadi A, Mohammadi Shahboulaghi F, Gillespie M. Respecting the privacy of hospitalized patients: An integrative review. Nurs Ethics. 2018:0969733018759832.

\section{[DOI:10.1177/0969733018759832] [PMID]}

3. Hasan Tehrani T, Seyed Bagher Maddah S, FallahiKhoshknab M, Ebadi A, Mohammadi Shahboulaghi F. Perception of hospitalized patients regarding respect for privacy. IJNR. 2018;13(1):79-86. [DOI:10.21859/ijnr-130111]

4. Friedman LA. Patient experience of privacy while participating in group healthcare: A phenomenographic description (Doctoral dissertation, Boston College).

5. Griffin-Heslin VL. An analysis of the concept dignity. Accid Emerg Nurs. 2005;13(4):251-7. [DOI:10.1016/j.aaen.2005.09.003] [PMID]

6. Parsapoor A, Bagheri A. Larijani b.[Patient rights in Iran]. J Med Ethics Hist Med. 2009:39-47.

7. Sanjari M, edtal. The code of Nursing ethics Iran. J Med Ethics Hist Med. 2011;5(1):17-28.

8. Parsapour A, Bagheri A, Larijani B. Patients' Bill of Rights in Iran. J Med Ethics Hist Med. 2010;3:39-47.

9. Gafarimanesh $\mathrm{H}$, rangbaran $\mathrm{M}$. The importance of privacy in the urology patient from the patient's perspective. J Kermanshah Univ Med Sci. 2014;18(4):251-5.

10. Jahanpour F, Rasti R. Viewpoints of nurses and patients on paying respect to the privacy of patients in care. Journal of Mazandaran University of Medical Sciences. 2014 Apr 15;24(111):34-42.

11. Hajbaghery MA, Chi SZ. Evaluation of elderly patients' privacy and their satisfaction level of privacy in selected hospitals in Esfahan. Medical Ethics Journal. 2015;8(29):97-120.

12. Moore M, Chaudhary R. Patients' attitudes towards privacy in a Nepalese public hospital: a cross-sectional survey. BMC research notes. 2013 Dec 1;6(1):31. [DOI:10.1186/1756-0500-6-31] [PMID] [PMCID]

13. Baillie L. Patient dignity in an acute hospital setting: a case study. International journal of nursing studies. 2009 Jan 1;46(1):23-37. [DOI:10.1016/i.ijnurstu.2008.08.003] [PMID]

14. Serenko N, Fan L. Patients' perceptions of privacy and their outcomes in healthcare. International Journal of Behavioural and Healthcare Research. 2013 Jan 1;4(2):101-22. [DOI:10.1504/IJBHR.2013.057359]

15. Woogara J. Patients' rights to privacy and dignity in the NHS. Nursing Standard (through 2013). 2005 Jan 12;19(18):33. [DOI:10.7748/ns.19.18.33.s50] [PMID]

16. Strauss LJ. Patient Privacy Impacts Quality. QualityJ of health care compliance. 2013;15(5):53-4.
17. Carpenter DR. Qualitative research in nursing: Advancing the humanistic imperative: Lippincott Williams \& Wilkins; 2011.

18. Swan M. Emerging patient-driven health care models: an examination of health social networks, consumer personalized medicine and quantified self-tracking. International journal of environmental research and public health. 2009 Feb;6(2):492-525. [DOI:10.3390/ijerph6020492] [PMID] [PMCID]

19. Graneheim UH, Lundman B. Qualitative content analysis in nursing research: concepts, procedures and measures to achieve trustworthiness. Nurse education today. $\quad 2004 \quad$ Feb $1 ; 24(2): 105-12$ [DOI:10.1016/j.nedt.2003.10.001] [PMID]

20. Polit DF, Beck CT. Essentials of nursing research: Appraising evidence for nursing practice: Lippincott Williams \& Wilkins; 2013.

21. Eklöf N, Abdulkarim H, Hupli M, Leino-Kilpi H. Somali asylum seekers' perceptions of privacy in healthcare. Nursing ethics. 2016 Aug;23(5):535-46. [DOI:10.1177/0969733015574927] [PMID]

22. Rasmussen TS, Delmar C. Dignity as an empirical lifeworld construction-In the field of surgery in Denmark. International journal of qualitative studies on health and well-being. 2014 Jan 1;9(1):24849. [DOI:10.3402/qhw.v9.24849] [PMID] [PMCID]

23. Manookian A, Cheraghi MA, Nikbakht Nasrabadi A, Peiravi H, Shali M. Nurses' lived experiences of preservation of patients' dignity. Iranian Journal of Medical Ethics and History of Medicine. 2014 May 15;7(1):22-33.

24. Chadwick A. A dignified approach to improving the patient experience: Promoting privacy, dignity and respect through collaborative training. Nurse Education in Practice. 2012 Jul 1;12(4):187-91. [DOI:10.1016/j.nepr.2011.12.006] [PMID]

25. Chochinov HM, Hack T, McClement S, Kristjanson L, Harlos M. Dignity in the terminally ill: a developing empirical model. Social science \& medicine. $2002 \mathrm{Feb}$ 1;54(3):433-43. 9536(01)00084-3]

[DOI:10.1016/S0277-

26. Whitehead J, Wheeler H. Patients' experiences of privacy and dignity. Part 1: a literature review. British Journal of Nursing. 2008 Mar 27;17(6):381-5. [DOI:10.12968/bjon.2008.17.6.28904] [PMID]

27. Akyüz E, Erdemir F. Surgical patients' and nurses' opinions and expectations about privacy in care. Nursing ethics. 2013 Sep;20(6):660-71. [DOI:10.1177/0969733012468931] [PMID]

28. Bäck E, Wikblad K. Privacy in hospital. Journal of Advanced Nursing. 1998;27(5):940-5. [DOI:10.1046/j.1365-2648.1998.t01-1-00576.x] [PMID]

29. Mazer SE. Lived-privacy: Understanding the variations in the ways patients make meaning of their privacy during hospitalization (Doctoral dissertation, Fielding Graduate University). 


$$
\text { •lf پيامدهاى رعايت حريم خصوصى بيماران بسترى در بيمارستان: تحليل محتواى كيفى }
$$

30. Johnson M. Notes on the tension between privacy and surveillance in nursing. OJIN: The Online Journal of Issues in Nursing. 2005 May 1;10(2).

31. Malcolm HA. Does privacy matter? Former patients discuss their perceptions of privacy in shared hospital rooms. Nursing Ethics. 2005 Mar;12(2):156-66. [DOI:10.1191/0969733005ne772oa] [PMID]

32. DeVoe JE, Wallace LS, Fryer Jr GE. Measuring patients' perceptions of communication with healthcare providers: do differences in demographic and socioeconomic characteristics matter?. Health Expectations. $2009 \quad$ Mar;12(1):70-80. [DOI:10.1111/j.1369-7625.2008.00516.x] [PMID] [PMCID]

33. Kaiser K, Rauscher GH, Jacobs EA, Strenski TA, Ferrans CE, Warnecke RB. The import of trust in regular providers to trust in cancer physicians among white, African American, and Hispanic breast cancer patients. Journal of general internal medicine. $2011 \mathrm{Jan}$ 1;26(1):51-7. [DOI:10.1007/s11606-010-1489-4] [PMID] [PMCID]

34. Association. AM. Code of medical ethics of the American Medical Association [Adobe Digital Editions version] www.amaassn.org/ama/pub/physician-resources/medicalethics/codemedical- ethics/code-medical-ethics.2015.

35. Sedaghani A. Evaluation of Health Care and Health Hospital standards. Fifth Edition ed. Tehran: Science and Art Publishing; 2014.

36. Abrahamnia M, Amerion A, Aziz A, Farahani M, Khadami V. Satisfaction rate of patients admitted to military hospitals from providing services. Journal of Military Medicine in the Pacific. 2011;12(2):101-5.

37. Farzianpour F, Foroushani AR, Sadeghi NS, Nosrati SA. Relationship between'patient's rights charter'and patients' satisfaction in gynecological hospitals. BMC health services research. 2016 Dec 1;16(1):476. [DOI:10.1186/s12913-016-1679-9] [PMID] [PMCID]

38. Aqajani M, dehghan nayeri N. Review of compliance with various aspects of the privacy of patients in the emergency department of the hospital, Tehran University of Medical Sciences. Journal of Medical Ethics and History of Medicine. 2010:59-69.

39. Marama T, Bayu H, Merga M, Binu W. Patient satisfaction and associated factors among clients admitted to obstetrics and gynecology wards of public hospitals in Mekelle town, Ethiopia: An InstitutionBased Cross-Sectional Study. Obstetrics and gynecology international. 2018;2018. [DOI:10.1155/2018/2475059] [PMID] [PMCID]

40. Hajbaghery MA, Chi SZ. Evaluation of elderly patients' privacy and their satisfaction level of privacy in selected hospitals in Esfahan. Medical Ethics Journal. 2015;8(29):97-120. 